\title{
Research activation energy in thermal modification of wood
}

\author{
Yuriy Tsapko ${ }^{1,2, *}$, Olga Bondarenko $^{2}$, Oleksandra Horbachova $^{1}$, Serhii Mazurchuk ${ }^{1}$, and Nataliya Buyskikh $^{1}$ \\ ${ }^{1}$ Kyiv National University of Construction and Architecture, Scientific Research Institute for Binders and Materials, 31 Povitroflotskyi \\ Ave, Kyiv, 03037, Ukraine \\ ${ }^{2}$ National University of Life and Environmental Sciences of Ukraine, 15 Heroiv Oborony Str., Kyiv, 03041, Ukraine
}

\begin{abstract}
The analysis of the process of thermal modification of wood, which was modified by a controlled process of pyrolysis of wood heating $\left(>180^{\circ} \mathrm{C}\right)$ in the absence of oxygen, which causes some chemical changes in the chemical structures of cell wall components (lignin, cellulose and hemicellulose), durability. It is proved that in the process of thermal modification the decomposition of hemicelluloses and the amorphous part of cellulose occurs, and therefore the amount of substances that are the environment for the development of fungi in wood significantly decreases. In addition, lignin and the formed pseudolignin undergo a process of polymerization and redistribution of cell volume and give cell walls greater density, hardness, increase hydrophobicity (water repellency), thereby reducing their ability to absorb moisture and edema. Polymerized lignin fills the inner cavity of the cell, forming a closed porous structure with a low ability to bind water. It was found that the most effective parameter for reducing such substances is the temperature and exposure time. The results of thermogravimetric researches are given, the dependence of weight loss on temperature of researches on the basis of which activation energy is calculated is defined. The results of determining the activation energy show that for hardwood species this value exceeds more than 1.5 times compared to softwood.
\end{abstract}

\section{Introduction}

Wood, as a building material, is widely used in construction and architecture due to its mechanical and operational properties. But under the influence of atmospheric factors it is destroyed. Due to the fact that these materials are sensitive to moisture and biological damage, ie the ability to maintain functional properties under operating conditions. It is possible to increase the level of operation of facilities that use building structures made of wood. The essence of the method is to give the wood the ability to resist moisture, the spread of biodamage, which contributes to the destruction of wood and accelerate the destruction process.

Given the above, the modification of wood difficulties for the application of technological modes like time, temperature. This is primarily due to the fact that the structure and composition of wood are different and the modification process is not achieved, and the use of thermodified wood leads to its destruction [1].

Knowledge of physical and chemical properties of substances such indicators of quality, the mechanism of action of the materials allows you to make their choice on the basis of economic performance, duration and application security, environmental aspects, etc. [2, 3]. And the application allows protection to maintain their function when operating within a specified period of time [4-6].

Therefore, the development of technological modes for wood modification, research in thermophysics, the influence of structural features, this process is an unresolved component of ensuring the stability of building structures made of wood. So it is necessitate the establishment of a thermal modification mechanism for such materials.

\section{Analysis of recent research and publications}

In recent years towards research on thermal modification of wood known work aimed at studying the equilibrium moisture during modification, dimensional stability, durability and mechanical properties of modified wood [7]. Loss of weight, wettability, color, wood and chemical transformations subsequently been widely studied. While the necessary works that focus on quality control, modeling and study of the causes of improved properties of the modified wood.

Thermomodified wood is one of the best materials for lining [8]. In this regard measured the moisture thermally modified heat and low moisture content of thermally modified wood in comparison with the standard spruce. But it is not specified what was the degree and modes of wood modification.

Increased use of thermally modified wood [9] led to the need for reliable quality control, including control of products deviations within certain limits, allowing you to control third party in the event of certification and regulation of the complaints and demands of consumers. However, it is not specified what methods are needed to

\footnotetext{
* Corresponding author: bondolya3@gmail.com
} 
characterize the change in quality in terms of improved target properties of modified wood during industrial production.

A study of changes in swelling and surface roughness of wood alder and elm normal after heat treatment at two different temperatures and duration [10]. Established that the parameters of swelling and surface roughness vary considerably for the two two-temperature heat treatment durations. The value of swelling and surface roughness decreased with increasing treatment temperature and time of treatment, but these technological parameters.

The characteristics of wood due to weather conditions change over time, especially the color, which reflects chemical changes [11]. An assessment of the change in color and reflectivity of wooden surfaces due to artificial weathering, obtained using a solar box chamber that simulates external conditions and subsequent leaching of water. As the weathering time increases, the untreated surfaces of the wood samples darken. While the modified samples lighten to have a similar color or, in any case, to reduce the chromatic difference that was at the beginning of the weathering tests.

During the heat treatment is many chemical reactions that lead to changes in the components of the primary cell walls of wood and darkening material. Among other changes, thermodified wood is more resistant to fungal decay and more stable at times than untreated. This make it suitable for use indoors and outdoors as cladding, flooring, floors, garden furniture and window frames [12].

Laboratory tests have shown the positive impact of thermal modification durability, dimensional stability and thermal conductivity of wood [13]. The monitoring results showed that the elements and windows of thermally modified spruce have a significantly lower moisture content in the wood compared to the windows of unmodified, and that the wax also has a positive effect on humidity.

Natural aging is usually a relatively slow process because the artificial aging plays a role important in assessing the results by reducing the time compared to the natural weathering conditions. The approach is to protect the surface with various types of commercial products such as water-based solvents with a high solids content, powder coatings and substance-free products [14].

One approach is the modification of wood, a set of processes that provide the treated material over the ability to cope with the damage caused by the environment, by increasing the duration of treatment. The process is also performed to enhance the physical, mechanical or aesthetic properties of wood and derived products with the advantage that is not harmful to users and the environment, as well as natural wood [15].

Several authors reported an increased resistance to decay for different wood species and several types of rots. The important degradation of hemicelluloses due to thermal treatment, which are generally considered as an important nutritive source as well as a prime key in the hygroscopic wood behavior for the development of wood rotting fungi. Modification of lignin network are also be involved to explain the ineffectiveness of fungal enzymatic attacks. These heat treated wood modifications are represented by mass loss (ML). Various authors compared the weight loss (WL) caused by fungal attack to the decrease in mass of wood by heat treatment (ML).

Wood heating will lead to different processes that always depend on the heating mode used. It is recognized that hemicelluloses are degraded to a greater extent than other macromolecular components, but the relative stability of cellulose and lignin is much more difficult to determine. As is not the case above, when the wood is heated, heat-labile wood polymeric components (hemicelluloses) begin to decompose, resulting in the production of methanol, acid, and various volatile heterocyclic compounds (furans, etc.). In general, the loss of polysaccharide material becomes particularly important at temperatures above $180{ }^{\circ} \mathrm{C}$, which largely depends on the processing conditions. However, changes in the degree of polymerization may appear at lower temperatures (above approx. $150^{\circ} \mathrm{C}$ ), depending on the heat treatment conditions. The total polyoses (hemicelluloses) containing a large proportion of xylan are oxidized more slowly and consume less oxygen than pure xylan. According to some studies, the decomposition of hardwood xylan begins at a temperature close to 200 ${ }^{\circ} \mathrm{C}$ in a normal atmosphere. Even though lignin is considered to be the thermally most stable component of wood, various changes have been observed even at temperatures below $200{ }^{\circ} \mathrm{C}$. Assessment of lignin content in thermally treated woods indicated the increase of nonhydrolyzable residue with increasing temperature up to $200{ }^{\circ} \mathrm{C}[16]$.

There are a number of thermal modification methods that can be applied to wood, and the exact method of treatment can have a significant effect on the properties of the thermally modified wood. Major process variables are the following: time and temperature of treatment, treatment atmosphere, pressure, closed vs. open systems, wood species, wet and dry systems, sample dimensions, and use of catalysts. Also, under certain conditions, changes in wood can be observed even at $100{ }^{\circ} \mathrm{C}$ [17].

Thermally modified wood has been produced for more than 20 years, mostly in Finland and other countries of Western Europe. It is made of non-durable and lessdurable wood species, such as beech, birch, pine, and spruce, etc. ThermoWood $\AA$ is produced by a heat treatment process in the presence of steam and is therefore typical hygrothermal treatment. The steam acts as a blanket to reduce the oxidative degradation of wood and there are also further reactions that occur due to the presence of moisture. Because of the presence of steam, the air content in the kiln is limited from 3 to $5 \%$ during the heat treatment process [18].

Thus, from the literature it is established that thermal modification of wood is able to withstand destruction. All this gives grounds to assert that it is expedient to conduct a study to determine the parameters that provide resistance to destruction, as well as influencing the mechanism of action in the protection of wood. Therefore, thermal analysis of wood, the influence of temperature and time on this process is an unresolved component of ensuring the stability of building structures made of wood, which necessitated research in this area. 
The purpose of this work is to study the activation energy of decomposition of wood and installation efficiency at thermal modification.

\section{Raw materials and methods}

To establish the mechanism of thermal modification of wood chips used samples of the wood as hornbeam, ash, pine. The weight of the sample was $190 \mathrm{mg}$.

Thermogravimetric study of thermal degradation processes in dynamic mode using derivatograph Q-1500 $\mathrm{D}$, heating rate -2.5 degrees per minute, a sample comparison - powder $\alpha$-corundum material crucibles alund sensitivity galvanometers, DTA - $250 \mathrm{mkV}$, DTG $-500 \mathrm{mkV}$.

\section{Results and discussion}

Direct data on the processes occurring in the samples of materials during their heating in the dynamic mode were obtained as a result of thermogravimetric studies. The results of the analysis of the studied materials are illustrated (Fig. 1, Table 1).

In the studied wood sample at temperatures from 75 to $100{ }^{\circ} \mathrm{C}$, endothermic processes take place, which are accompanied by a loss of up to $6 \%$ of their mass. Such processes are caused by the evaporation of chemically unbound water without destruction of the sample material. In addition, organic matter loses constitutional water (endoeffect with a maximum of $150{ }^{\circ} \mathrm{C}$ with additional weight loss). In the temperature range $180-250{ }^{\circ} \mathrm{C}$, the temperature range often used for heat treatment, wood undergoes important chemical transformation. And at temperatures above $250 \quad{ }^{\circ} \mathrm{C}$ begins carbonization processes with the formation of $\mathrm{CO}^{2}$ and other pyrolysis products $[19,20]$.

Hemicelluloses are the first structural compounds to undergo thermal action, even at low temperatures (about $140{ }^{\circ} \mathrm{C}$ ). It should be noted that the basis of nutrition of biological pests of wood is hemicellulose and the amorphous part of cellulose, and the defeat of wood by different types of fungi and mold is possible only at high humidity. Because hemicelluloses are hygroscopic and intensively absorb and bind moisture, hemicelluloses create favorable conditions for the development of fungi and mold on wood. The decomposition of hemicellulose begins with deacetylation, and acetic acid is released, which acts as a catalyst for depolymerization, which further increases the decomposition of the polysaccharide. In addition, lignin and the formed pseudolignin undergo repolymerization and redistribution in cell volume. They give the cell walls greater density, hardness, increase hydrophobicity (water repellency), thereby reducing their ability to absorb moisture and swell. Repolymerized lignin fills the inner cavity of the cell - forming a closedporous structure with a low ability to bind water. For Scots pine, which is treated at temperatures from $205^{\circ} \mathrm{C}$ to $230{ }^{\circ} \mathrm{C}$ for $4-8$ hours, the lignin content increases from $24.5 \%$ to $38.7 \%$, respectively, and the hemicellulose content decreases [21].

The temperature at which the intensive destruction of wood begins, ie there is a rapid loss of mass of the samples, is $215-250{ }^{\circ} \mathrm{C}$. In particular, exothermic oxidation processes take place in a wood sample along with endothermic pyrolysis processes (cleavage of volatile products) even at relatively low temperatures. The main increase in weight loss in the temperature range of $180-220^{\circ} \mathrm{C}$ occurred due to the extractives of water and ethanol as a result of polysaccharide degradation. During heat treatment, the formation of liquid and gaseous phases in addition to solid wood. The liquid phase at temperatures of $200-250{ }^{\circ} \mathrm{C}$ is almost exclusively water and acetic acid with small amounts of formic acid, furfural and methanol [22]. Acids catalyze the decomposition of polysaccharides and reduce their content (Table 1).

Thus, the thermogravimetric parameters enable to determine the rate of thermal decomposition of the material at a given temperature and therefore show a qualitative assessment of the effects of heat, but more important task is to determine the activation energy thermooxidative degradation.

Table 1. The results of research on wood samples.

\begin{tabular}{|c|c|c|c|c|c|c|}
\hline \multicolumn{7}{|c|}{ Pine wood } \\
\hline \multicolumn{7}{|c|}{ Mass loss (\%) for temperatures } \\
\hline $76^{\circ} \mathrm{C}$ & $140^{\circ} \mathrm{C}$ & $150^{\circ} \mathrm{C}$ & $160^{\circ} \mathrm{C}$ & $190^{\circ} \mathrm{C}$ & $200^{\circ} \mathrm{C}$ & $220^{\circ} \mathrm{C}$ \\
\hline 1,5 & 2,1 & 3,2 & 4,1 & 5,3 & 6,0 & 6,5 \\
\hline \multicolumn{7}{|c|}{ Mornbeam wood } \\
\hline $76^{\circ} \mathrm{C}$ & $140^{\circ} \mathrm{C}$ & $150^{\circ} \mathrm{C}$ & $160^{\circ} \mathrm{C}$ & $190^{\circ} \mathrm{C}$ & $200^{\circ} \mathrm{C}$ & $220^{\circ} \mathrm{C}$ \\
\hline 1,2 & 1,3 & 2,6 & 3,7 & 4,4 & 5,8 & 6,2 \\
\hline \multicolumn{7}{|c|}{ Ash wood } \\
\hline \multicolumn{7}{|c|}{ Mass loss (\%) for temperatures } \\
\hline $76^{\circ} \mathrm{C}$ & $140^{\circ} \mathrm{C}$ & $150^{\circ} \mathrm{C}$ & $160^{\circ} \mathrm{C}$ & $190^{\circ} \mathrm{C}$ & $200^{\circ} \mathrm{C}$ & $220^{\circ} \mathrm{C}$ \\
\hline 1,3 & 1,4 & 2,8 & 4,2 & 4,9 & 6,1 & 6,4 \\
\hline
\end{tabular}

Calculation of kinetic parameters TG curve, which satisfactorily describes the kinetics of decomposition of solids based on the equation [22-23]:

$$
-\frac{\mathrm{dm}}{\mathrm{dt}}=\mathrm{k} \cdot \mathrm{m}^{\mathrm{n}}
$$

where is the

$\mathrm{m}$ - the mass of the sample that entered the decomposition reaction, $\mathrm{mg}$;

$\mathrm{n}$ - reaction order;

$\mathrm{k}$ - specific reaction rate of decomposition of the material.

The dependence of the specific decomposition rate of the material on temperature is described by the Arrhenius equation:

$$
\mathrm{k}=\mathrm{A} \cdot e(-\mathrm{E} / \mathrm{RT})
$$

where is the

A - preexponential multiplier;

$e$ - activation energy, $\mathrm{kJ} / \mathrm{mol}$;

$\mathrm{R}$ - universal gas rack, 8,314 $\mathrm{kJ} /(\mathrm{mol} \cdot \mathrm{K})$.

For separate stages of destruction, a possible method of calculating the activation energy is the method described in [23], which shows that the parameter E, under other equivalent conditions, is a measure of resistance to thermal oxidative destruction of the material. 
The following decomposition scheme is typical for wood:

$$
\mathrm{A}_{(\text {тв })} \rightarrow \mathrm{B}_{(\text {тв })}+\mathrm{C}_{(\text {газ) }}
$$

and determining the speed of decomposition reaction enables the equation:

$$
-\frac{\mathrm{dm}}{\mathrm{dT}}=\frac{\mathrm{A}}{\mathrm{V}_{\text {нагр }}} \cdot \mathrm{e}^{-\mathrm{E} / \mathrm{RT}} \cdot \mathrm{m}^{\mathrm{n}} .
$$

The calculation of $E$ and $n$ is based on the mathematical processing of the TG curve using the dependence [15]:

$$
\ln \left(\ln \frac{100}{100-\Delta \mathrm{m}}\right)=-\frac{\mathrm{E}}{\mathrm{R}} \cdot \frac{1}{\mathrm{~T}} \text {. }
$$

In this equation $\Delta \mathrm{m}-$ mass loss $(\%)$ at each temperature in the range of decomposition of the material, which is the process of the first order $(n=1)$ and provided depending linearization:

$$
\ln \left(\ln \frac{100}{100-\Delta \mathrm{m}}\right)=\ln (\ln 100 /(100-\Delta \mathrm{m}))
$$

from temperature $\mathrm{T}, \mathrm{K}$.

In Fig. 1 shows a graphical dependence of the rate of destruction of wood on the inverse temperature. The value of the activation energy $(\mathrm{E})$ is calculated depending on:

$$
\mathrm{E}=\operatorname{tg} \phi \cdot \mathrm{R}
$$

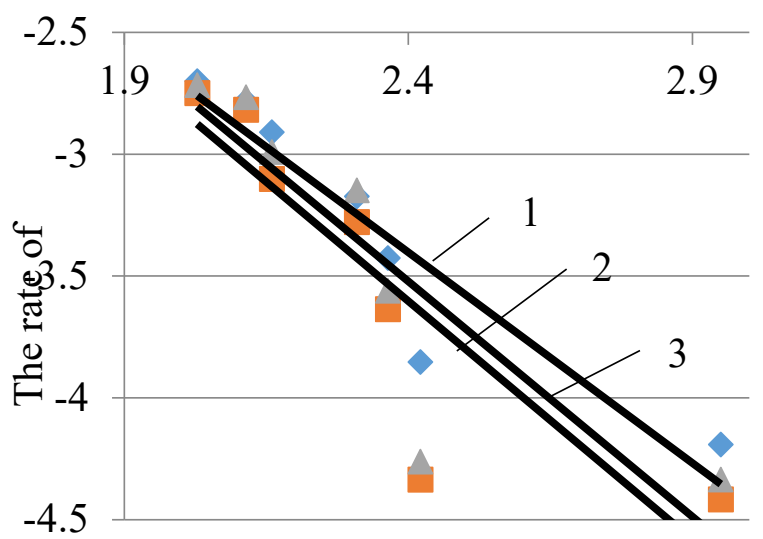

Inverse temperature, 1000 /

Fig. 1. Graphic dependence of the rate of thermal destruction of wood on the inverse temperature: 1 - pine; 2 - hornbeam; 3 - ash.

Table 2 shows the results of thermal analysis and calculation of the parameters required to determine the activation energy of the treated wood.

As can be seen from Table 3, pyrolysis of hardwood requires more activation energy, and therefore requires costs in its thermal modification, namely time and temperature.

One of most interesting property of heat-treated wood remains its decay resistance. Durability test with modified wood in laboratory are expensive and time-consuming. This review displays data from different analytical methods, such as spectroscopy, thermogravimetry, chemical analyses or mechanical tests that have the potential to be valuable indicators to assess the durability of heat treated wood at industrial scale. However, each

\begin{tabular}{|c|c|c|}
\hline $\mathbf{t}, \mathbf{K}$ & $\Delta \mathrm{m}, \%$ & $\operatorname{Ln}(\operatorname{Ln}(100 / 100-\Delta m))$ \\
\hline \multicolumn{3}{|c|}{ Pine wood } \\
\hline 339 & 1,5 & 0,878774 \\
\hline 413 & 2,1 & 0,834032 \\
\hline 423 & 3,2 & 0,475885 \\
\hline 433 & 4,1 & 0,103154 \\
\hline 463 & 5,3 & $-0,25292$ \\
\hline 473 & 6,0 & $-0,87824$ \\
\hline 493 & 6,5 & $-1,35181$ \\
\hline \multicolumn{3}{|c|}{ Hornbeam wood } \\
\hline 339 & 1,2 & 0,744 \\
\hline 413 & 1,3 & $-0,066$ \\
\hline 423 & 2,6 & $-0,26$ \\
\hline 433 & 3,7 & $-0,83$ \\
\hline 463 & 4,4 & $-1,04$ \\
\hline 473 & 5,8 & $-1,43$ \\
\hline 493 & 6,2 & \\
\hline \multicolumn{3}{|c|}{ Ash wood } \\
\hline 339 & 1,3 & 0,86 \\
\hline 413 & 1,4 & 0,44 \\
\hline 423 & 2,8 & $-0,02$ \\
\hline 433 & 4,2 & $-0,27$ \\
\hline 463 & 4,9 & $-0,59$ \\
\hline 473 & 6,1 & $-0,80$ \\
\hline 493 & 6,4 & \\
\hline
\end{tabular}
method has its limits and drawbacks, such as the required investment for the equipment, reliability and accuracy of the results and ease of use at industrial scale.

Table 2. The results of thermal analysis.

Table 3 shows the values of activation energy during thermal decomposition of wood.

Table 3. The calculated value of the activation energy during thermal decomposition of wood.

\begin{tabular}{|c|c|c|}
\hline $\begin{array}{c}\text { Number } \\
\text { in order }\end{array}$ & Wood & $\begin{array}{c}\text { Activation energy, } \\
\mathbf{E}, \mathbf{k J} \text { / mol }\end{array}$ \\
\hline 1 & Pine & 13,47 \\
\hline 2 & Hornbeam & 23,28 \\
\hline 3 & Ash & 19,95 \\
\hline
\end{tabular}

There is a partial increase in the values of most properties at a lower treatment temperature, eventually leading to the preservation of values at the level of untreated wood. Thus, for birch, the modulus of rupture increased by $26 \%$, the modulus of elasticity by $24 \%$, and the hardness in the radial plane by $34 \%$. This is related to the fact that chemical changes are not yet significant, and they only case the restriction of the wood's ability to absorb bound water.

With higher treatment temperatures, there is a decrease in the elastic and especially the strength properties of the heat-treated wood. At higher treatment temperatures, more markedly right above $200{ }^{\circ} \mathrm{C}$, the significant reduction of equilibrium moisture has no such effect as the consequence of more significant changes in the chemical structure of wood and the decrease in properties is significant. 
Apparently, wood with a higher hemicellulose content, i.e., a lower overall resistance, exhibits a lower density, static bending strength, and toughness. Therefore, a more significant decrease was observed for the beech and birch woods than for the softwoods at higher treatment temperatures. The decrease of toughness by about $81 \%$ for beech wood with treated temperatures of $210{ }^{\circ} \mathrm{C}$ was observed in comparison to untreated wood (respectively $86 \%$ at birch). Static bending strength at heat treated birch wood decreased by $47 \%$ (respectively $59 \%$ at beech) [25-27].

The higher strength resistance (respectively mainly hardness) of birch wood compared to beech in relation to heat treatment has been demonstrated, which is probably due to the higher content of mannan fractions of hemicelluloses) [28-30].

The existing correlation between static and dynamic modules of elasticity was confirmed, but it was not statistically significant in all cases.

Our research confirmed that although untreated birch wood is not equal to beech wood from the view of wood properties, the heat treatment provides wood of similar properties. The impact of the heat treatment on the wood properties is less pronounced in the case of birch than beech, and the birch is thus more suitable for thermal modification. This simple and environmentally friendly method provides one of the ways to increase the utilization of birch wood in the industry for more valuable products than fuelwood.

Thermal modification of wood is an environmentfriendly alternative method for improving several properties of wood without the use of chemicals. This paper deals with the examination of color and chemical changes in spruce (Picea abies L.) and oak wood (Quercus robur F.) that occur due to thermal treatment. The thermal modification was performed at $160{ }^{\circ} \mathrm{C}, 180{ }^{\circ} \mathrm{C}$ and 210 ${ }^{\circ} \mathrm{C}$ according to thermowood process. The color changes were measured by the spectrophotometer and described in the $\mathrm{L}^{*} \mathrm{a} * \mathrm{~b} *$ color system. Chemical changes were examined by wet chemistry methods, infrared spectroscopy and liquid chromatography. During the experiment, oak samples showed smaller color changes than spruce samples at all temperature values. During thermal modification, the content of cellulose, lignin and extractives increases, however the hemicelluloses content drops by $58.85 \%$ (oak) and by $37.40 \%$ (spruce). In addition to deacetylation, new carbonyl and carboxyl groups are formed as a result of oxidation. Bonds in lignin (mainly $\beta-\mathrm{O}-4$ ) and methoxyl groups are cleaved, and lignin is condensed at higher temperatures.

\section{Conclusion}

Thus, the calculation revealed that the thermal decomposition of pine wood requires much less activation energy than the decomposition of hornbeam and ash wood.

The research results will also further signifies our strong resolve problems concerning the development of new means and methods of obtaining organic materials and operating conditions at different sites.
Authors express their gratitude to the Ministry of Education and Science of Ukraine for financial support of the research, that was performed in the framework of budget funding No. 3 DB-2018, as well as for the development of the theme of research according to the program of scientific cooperation COST Action FP 1407 "Understanding the modification of wood through an integrated scientific and environmental approach" of the European Union's framework program HORIZON 2020.

\section{References}

1. Lo Monaco, A., Pelosi, C., Agresti, G., Picchio, R., Rubino, G.: Influence of thermal treatment on selected properties of chestnut wood and full range of its visual features. Drewno 63 (205), 5-24 (2020)

2. Krivenko, P., Petropavlovskyi, O., Kovalchuk, O., Rudenko, I., Konstantynovskyi, O.: Enhancement of alkali-activated slag cement concretes crack resistance for mitigation of steel reinforcement corrosion. E3S Web of Conferences 166, $06001 \quad$ (2020) doi: $10.1051 / \mathrm{e} 3$ sconf/202016606001

3. Krivenko, P.V., Petropavlovskyi, O.M., Rudenko, I.I., Konstantynovskyi, O.P., Kovalchuk, A.V.: Alkali-activated portland cement with adjustable proper deformations for anchoring application. IOP Conference Series: Materials Science and Engineering (MSE) 708, 012090 (2019) doi:10.1088/1757899X/708/1/012090

4. Tsapko, Y., Tsapko, A., Bondarenko, O.: Establishment of heatexchange process regularities at inflammation of reed samples. Eastern-European Journal of Enterprise Technologies 1 (10-97), 36-42 (2019). doi: 10.15587/1729-4061.2019.156644

5. Tsapko, Y.V., Tsapko, A.Yu., Bondarenko, O.P., Sukhanevych, M.V., Kobryn, M.V.: Research of the process of spread of fire on beams of wood of fireprotected intumescent coatings. IOP Conference Series: Materials Science and Engineering 708, 012112 (2019). doi:10.1088/1757-899X/708/1/012112

6. Bondarenko, O., Guzii, S., Zaharchenko, E., Novoselenko, E.: Development of protective materials based on glass- and slag-containing portland cement structures Eastern-European Journal of Enterprise Technologies $6 \quad(\mathbf{1 1 - 7 8}), 41-47 \quad$ (2015). doi: 10.15587/1729-4061.2015.56577

7. Esteves, B., Pereira, H.: Wood modification by heat treatment. A review. Bioresources 4 (1), 370-404 (2009) http://ncsu.edu/bioresources

8. Humar, M., Lesar, B., Kržišnik, D.: Moisture Performance of Façade Elements Made of Thermally Modified Norway Spruce Wood. Forests 11 (3), 348 (2020). doi: 10.3390/f11030348

9. Humar, M., Repič, R., Kržišnik, D., Lesar, B.: Quality Control of Thermally Modified Timber Using Dynamic Vapor Sorption (DVS) Analysis. Forests 11 (6), 666 (2020). doi: 10.3390/f11060666

10. Aytin, S., Korkut, P.: Effect of thermal treatment on the swelling and surface roughness of common alder and wych elm wood. Journal of Forestry Research 27(1), 225-229 (2016). 


\section{doi: 10.1007/s11676-015-0136-7}

11. Pelosi, G., Agresti, L., Lanteri, R., Picchio, E., Gennari, E., Lo Monaco, A.: Artificial Weathering Effect on Surface of Heat-Treated Wood of Ayous (Triplochiton scleroxylon K. Shum). Conference: The 1st International Electronic Conference on Forests (IECF) https://sciforum.net/conference/IECF2020

12. Ugovšek, B., Šubic, G., Humar, M., Lesar, B., Thaler, N., Brischke, C., Jones, D., Lozano, J.I.: Performance of Windows and façade elements made of thermally modified Norway spruce (Picea abies) in different climatic conditions. In Proceedings of the WCTE 2016-World Conference on Timber Engineering (2016). doi: 10.1007/s1 1998-016-9871-8

13. Ugovšek, B., Šubic, G., Starman, J., Rep, G., Humar, M., Lesar, B., Thaler, N., Brischke, C., Meyer-Veltrup, L., Jones, D., Häggström, U., Lozano, J.I.: Short-term performance of wooden windows and facade elements made of thermally modified and non-modified Norway spruce in different natural environments. Wood Material Science and Engineering 14, 42-47 (2019). https://doi.org/10.1080/17480272.2018.1494627

14. Bonifazi, G., Serranti, S., Capobianco, G., Agresti, G., Calienno, L., Picchio, R., Lo Monaco, A., Santamaria, U., Pelosi, C.: Hyperspectral imaging as a technique for investigating the effect of consolidating materials on wood. Journal of Electronic Imaging 26 (1), 011003 (2017)

15. Jones, D., Sandberg, D., Goli, G., Todaro, L.: Wood Modification in Europe: a state-of-the-art about processes, products and applications. International, metadata CC0 1.0 Universal, published by Firenze University Press (2019). doi: 10.36253/978-88-6453970-6

16. Fengel, D., Wegener, G.: Wood: Chemistry, Ultrastructure, Reactions, 2nd ed. Walter de Gruyter (Berlin, Germany, 1989). doi: https://doi.org/10.1515/9783110839654

17. Garrote, G., Domínguez, H., Parajó, J.C.: Hydrothermal processing of lignocellulosic materials. Holz als Roh- und Werkstoff 57, 191-202 (1999). https://doi.org/10.1007/s001070050039

18. Hill, C.A.S.: Wood Modification: Chemical, Thermal and Other Processes (London, UK, John Wiley \& Sons, 2006)

19. Bourgois, J., Bartholin, M., Guyonnet, R.: Thermal treatment of wood: Analysis of the obtained product. Journal Wood Sci. Technol. 23, 303-310 (1989)

20. Tjeerdsma, B., Militz, H.: Chemical changes in hydroheat wood: FTIRanalysis of combined hydroheat and dry heat-treated wood. Holz RohWerkst 63, 102-111 (2005).

21. Sivonen, H., Maunu, S., Sundholm, F., Jämsä, S., Viitaniemi, P.: Magneticresonance studies of thermally modified wood. Holzforschung 56, 648-654 (2002).
22. Nuopponen, M., Vuorinen, T., Jamsä, S., Viitaniemi, P.: Thermalmodifications in softwood studied by FT-IR and UV resonance Ramanspectroscopies. Journal Wood Chem. Technol. 24, 13-26 (2004)

23. Shestak, J.: Theory of thermal analysis (Moscow, Mir, 1987)

24. Broido, A.: A simple sensitive graphical method of treating thermogravimetry analyse data. Journal Polym. Sci. Part A 7 (2), 1761-1773 (1969)

25. Boonstra, M.J., Tjeerdsma, B., Pizzi, A., Tekely, P., Pendlebury, J.: Chemical modification of Norway spruce and Scots pine: a 13C NMR CP-MAS study of the reactivity and reactions of polymeric wood components 50, 215- 220 (1996)

26. Candelier, K., Dumarçay, S., Pétrissans, A., Gérardin, P., Pétrissans, M.: Mechanical properties of heat treated wood after thermodegradation under different treatment intensity. International Conference "Mechano-chemical transformations of wood during thermo-hydro-mechanical processes" (2011). doi: 10.4067 / S0718-221X2015005000024

27. Candelier, K., Hannouz, S., Elaieb, M.T., Collet, R., Dumarçay, S., Pétrissans, A., Gérardin, P., Pétrissans, M.: Utilization of temperature kinetic as a method to predict treatment intensity and corresponding treated wood quality: durability and mechanical properties of thermally modified wood. Maderas-Ciencia Tecnologia 17, 253-262 (2015). http://dx.doi.org/10.4067/S0718$221 \times 2015005000024$

28. Hamada, J., Petrissans, A., Mothe, F., Petrissans, M., Gerardin, P.: Analysis of the effects of the European oak natural variability on the modification of the density distribution and chemical composition during the heat treatment. Proceedings of the Joint focus workshop of COST Action FP1006 \& FP0904 (2013). doi: 10.1007/s13595-015-0499-0

29. Dibrova, O., Kyrychenko, O., Motrichuk, R., Tomenko, M., Melnyk, V.: Fire safety improvement of pyrotechnic nitrate-metal mixtures under external thermal conditions. Technology Audit and Production Reserves 1 (51), 44-49 (2020). doi: https://doi.org/ $10.15587 / 2312-8372.2020 .199252$

30. Krüger, S., Gluth, G.J.G., Watolla, M.-B., Morys, M., Häßler, D., Schartel, B.: Neue Wege: Reaktive Brandschutzbeschichtungen für Extrembedingungen.

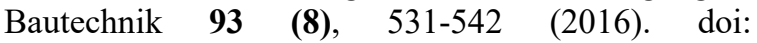
https://doi.org/10.1002/bate.201600032 